\title{
Employee Performance at the Office of Population and Civil Registration in North Morowali Regency
}

\author{
Jumiani $^{1}$, Syahruddin Hattab ${ }^{2}$, Muhammad Faisal ${ }^{3}$ \\ 1.2 Universitas Tadulako \\ ${ }^{3}$ Institut Pemerintahan Dalam Negeri (IPDN), Sulawesi Selatan \\ E-mail: Jumianibasir077@gmail.com
}

(Received: December-2017; Reviewed: January-2018; Accepted: February-2018;

Avalaibel Online: February-2018; Published: March-2018)

(7) (8) This is an open access article distributed under the Creative Commons Attribution License CC-BY-NC-4.0 @2018 by author (https://creativecommons.org/licenses/by-nc/4.0/)

\begin{abstract}
This study aims to find out how the Performance of Employees in the Office of Population and Civil Registry of North Morowali Regency. This type of research used is descriptive and the basic research used is qualitative research methods. The informants in this study were determined positively by the number of informants as many as 7 people, data collection techniques through observation, interviews and documentation. In this study using Suyadi Prwirasentono's theory, where there are 4 (four) indicators that there are employee performance at the Office of Population and Civil Registration of North Morowali Regency in terms of effectiveness, authority and responsibility, discipline, initiative. Based on the results of existing research that the performance of employees at the Office of Population and Civil Registry of North Morowali Regency is considered quite good.
\end{abstract}

Keywords: effectiveness; responsibility; discipline; initiative.

\section{INTRODUCTION}

Government is a group of people who manage the authorities of the institutions where they are placed as personifications of power. So, if the rules of the game and institutions are two abstract and static components of a government system, the bureaucratic apparatus and political officials who sit in the three branches of government are concrete, active and dynamic components (Badjido \& Samad, 2014)

State management certainly cannot be separated from the role of the government apparatus as the main driver of the running of the government. The State Civil Apparatus (ASN) as the government apparatus and public servants as the most important assets that spearhead in carrying out the tasks of the responsibility of government agencies is to carry out the functions of service, development and empowerment to the community as beneficiaries, therefore every government agency must realize excellent service where these objectives will not be achieved if it is not supported by maximum performance. Bureaucracy in Indonesia has certain 
characteristics, so people are often allergic when dealing with bureaucracy (Amirullah \& Darwis, 2015; Astini, Wijaya, \& Muluk, 2015; Siagian, Sondang, 2004).

Coordination is defined as an activity carried out by various parties that are equal to provide information and arrange together (agree) certain things, so that on one hand the process of carrying out the tasks and the success of one party does not interfere with the process of carrying out the tasks and success of the other party, while on the other hand one directly or indirectly supports the other party.

Government efforts in providing optimal public services are important to do (Hardiansyah, 2011; Kamaruddin Sellang, 2016; Rukayat, 2017). Public services must get serious attention because they are the main tasks and functions inherent in the government apparatus. The level of quality of public service performance has broad implications in various aspects of life, especially to achieve the level of community welfare. Therefore efforts to improve public services must be carried out continuously and carried out by all levels of the local government apparatus (Enggarani, 2016; Maryam, 2016; Mirnasari, 2013). The quality of public services is generally determined by several aspects, namely: systems, institutions, human resources, and finance in the administration of public services. Public services, as is the case in many other countries, include education, health, public transportation, housing, social welfare, electricity and drinking water provided by government bureaucracy with the aim of improving citizens' welfare (Hartley, 2005; Seaden \& Manseau, 2001 ; Ziman, 1991)

Employee performance is the result of quality and quantity of work achieved by an employee in carrying out their duties in accordance with the responsibilities given to him (Mangkunegara, 2003, 2016). Improved employee performance is important given the change in direction of government policy as desired by the spirit of reform to broader provide space and greater participation for the community in government and development activities (Kompaso \& Sridevi, 2010; Shahzadi, Javed, Pirzada, Nasreen, \& Khanam, 2014; William, 2010). Where the government and apparatus have more roles as facilitators. This change in policy direction has implications for the ability of professionalism of employees in responding to the challenges of the globalization era in the face of tight competition with other countries in the world. Starting from this thought, the improvement in the performance of the apparatus is an urgent matter that must be carried out today for the sake of the good aspects of government as a subject in the implementation of servants and the community which are the objects of recipients of these services.

Employee Performance at the Department of Population and Civil Registration of North Morowali Regency as a government agency that is bound by its main duties and functions in service to the community certainly cannot be separated from the process and results of the achievement at the end of work, in this case employee performance is the work of employees both in terms of quality and quantity based on predetermined performance standards that have been achieved by the Department of Population and Civil Registration of North Morowali Regency in carrying out their duties in accordance with their responsibilities. Performance is the achievement of results (outcomes) at the level or unit of the organization, performance at the organizational level is related to organizational goals, organizational design, and organizational management legally, does not violate the law and a long process other than by improving the quality of performance towards the better. conducted by employees of the Office of Population and Civil Registration in North Morowali Regency. 


\section{METHOD}

This type of research is a qualitative descriptive study. The types of data used are primary data and secondary data. Data collection techniques used are observation, interviews, documentation and triangulation. Data analysis consists of data collection, data condensation, data presentation and drawing conclusions.

\section{RESULT AND DISCUSSION}

Morowali Regency Uatara Regency Population and Civil Registry Office staff are demanded to have good performance in carrying out government duties, because as employee performance, it is used as a benchmark by the community to assess the effectiveness and efficiency of carrying out the duties of employees in providing services to the community.

\section{Employee Effectiveness}

Employee effectiveness is the beginning of organizational success, because the effectiveness of individuals (employees) will produce group-level effectiveness, the effectiveness of this group moves in an organization that has a common goal or bias said the level of organizational effectiveness in this case the Office of Population and Civil Registry of Morowali Regency North, intended to be able to achieve organizational goals in accordance with a predetermined time.

\section{Employee Discipline}

Based on the results of disciplinary research the attendance of employees does not comply with applicable rules. The delay is due to outside constraints such as those who are already taking care of the household and taking care of the children, organizing the school first and the existing authority as an office employee is late entering the office. Although this is the case, employees who are late in adding office hours out of hours determined by the rules.

\section{Employee Authority and Responsibility}

Responsibility is a very important thing that must be owned by every individual, as well as in the scope of the organization, the attitude of responsibility that grows from an employee will have an impact on the applied aspects of exercising authority that will be delegated by superiors. Based on the research results, the authority and responsibility of the employees are good enough, but professionalism and work enthusiasm have not been maximized and the sanctions given have not been maximized.

\section{Employee Initiative}

Initiative is the ability for someone to decide and do something right without having to be told, able to find what should be done about something that is around, trying to keep moving 
and doing something with good ideas. Based on the results of the study, employee initiatives are in the quite good category, this is seen from the awareness in an employee in the demands of work is still not optimal.

\section{Discussion}

\section{Employee Effectiveness}

Each employee is required to have the ability of human resources so that in carrying out a job can be completed within the allotted time. If the target is achieved and can be said to be effective, and vice versa if the target cannot be achieved according to the target, then it can be said then the results of the work are less effective.

\section{Employee Discipline}

Work discipline can be defined as an attitude of respect, respect, obedience and obedience to the applicable regulations, both written and unwritten and able to run without avoiding to accept what sanctions if they violate the duties and authority given to him. Discipline is a management action that encourages employees to meet various standards that must be met by employees. The provisions set by the organization are certainly an emphasis on each individual employee.

\section{Employee Authority and Responsibility}

Responsibility is a very important thing that must be owned by every individual, as well as in the scope of the organization, the attitude of responsibility that grows from an employee will have an impact on the applied aspects of exercising authority that will be delegated by superiors. Each employee is equipped with the authority to carry out work and to adhere to the inherent or accountability authority. Authority and responsibility must be balanced. Every job must be able to provide accountability in accordance with the authority. Therefore, the smaller the authority the smaller the responsibility and vice versa.

\section{Employee Initiative}

Every human being must have an initiative that distinguishes the levels, there are low and high tones, the level of initiative is directly proportional to the level of risk, low initiative employees will get little or no risk because he works according to orders, while employees who have the initiative high will have a high risk too. But the high risk will be followed by the success obtained when funding initiatives work steps taken with a good idea or idea base (Sentono, 2012).

\section{CONCLUSION}


Based on the results of the study, the organizational performance of the Palu City Regional Disaster Management Agency office is still not good, seen from the indicators of productivity, service quality, responsiveness, responsibility, and accountability. Even though the indicators of responsibility and accountability have received quite good responses from the community, but indicators of productivity, service quality, and responsiveness still need more attention from the office of the Palu City Disaster Management Agency.

\section{REFERENCES}

Amirullah, A. H., \& Darwis, M. (2015). Upaya Peningkatan Kinerja Pegawai pada Biro Administrasi Akademik dan Kemahasiswaan Universitas Negeri Makassar. Jurnal Office, 1(2), 180-184.

Astini, F. N., Wijaya, A. F., \& Muluk, M. R. K. (2015). Empirical Study Praktek Inovasi Birokrasi dalam Penanganan Permasalahan Gelandangan di Kota Surabaya. Jurnal Ad'ministrare: Jurnal Pemikiran Ilmiah dan Pendidikan Administrasi Perkantoran, 2(2), 53-62.

Badjido, M. Y., \& Samad, A. (2014). Peran pemerintah daerah dalam pemberdayaan masyarakat petani kakao di desa kayuangin kecamatan malunda kabupaten majene. IV(1), $45-54$.

Enggarani, N. S. (2016). Kualitas Pelayanan Publik dalam Perizinan di Pelayanan Terpadu Satu Pintu (PTSP) Kantor Badan Penanaman Modal dan Pelayanan Perizinan Terpadu (BPMP2T) Kabupaten Boyolali. Law and Justice. https://doi.org/10.23917/laj.v1i1.2702

Hardiansyah. (2011). Kualitas Pelayanan Publik. KUALITAS PELAYANAN PUBLIK MENUJU GOOD LOCAL GOVERNANCE. https://doi.org/10.1016/j.jhsa.2008.07.013

Hartley, J. (2005). Innovation in governance and public services: Past and present. Public Money and Management. https://doi.org/10.1111/j.1467-9302.2005.00447.x

Kamaruddin Sellang. (2016). Administrasi dan Pelayanan Publik Antara Teori dan Aplikasi. In Akmen.

Kompaso, S. M., \& Sridevi, M. S. (2010). Employee Engagement: The Key to Improving Performance. International Journal of Business and Management. https://doi.org/10.5539/ijbm.v5n12p89

Mangkunegara, A. A. A. P. (2003). Manajemen Sumber Daya Manusia Perusahaan. In Remaja Rosdakarya. https://doi.org/10.1038/cddis.2011.1

Mangkunegara, A. A. A. P. (2016). Evaluasi Kerja. In PT.Refika Aditama. https://doi.org/10.1038/cddis.2011.1

Maryam, N. S. (2016). Mewujudkan good governance melalui pelayanan publik. Jurnal Ilmu Politik dan Komunikasi. 


\section{$108 \mid$ Pinisi Discretion Review}

Volume 1, Issue 1, September, 2017. Pages 103-108

Mirnasari, R. M. (2013). Inovasi Pelayanan Publik UPTD Terminal Purabaya-Bungurasih. Kebijakan dan Manajemen Publik.

Rukayat, Y. (2017). Kualitas Pelayanan Publik Bidang Administrasi Kependudukan Di Kecamatan Pasirjambu. Jurnal Ilmiah Magister Ilmu Administrasi (JIMIA).

Seaden, G., \& Manseau, A. (2001). Public policy and construction innovation. Building Research and Information. https://doi.org/10.1080/09613210010027701

Shahzadi, I., Javed, A., Pirzada, S. S., Nasreen, S., \& Khanam, F. (2014). Impact of Employee Motivation on Employee Performance. European Journal of Business and ManagementOnline).

Siagian, Sondang, P. (2004). Teori Motivasi dan Aplikasinya. Jakarta: PT Rineka Cipta. https://doi.org/10.24034/j25485024.y2016.v20.i4.1826

William, A. N. (2010). Employee motivation and performance. Business Management.

Ziman, J. (1991). Public Understanding of Science. Science, Technology \& Human Values. https://doi.org/10.1177/016224399101600106 